University of Nebraska - Lincoln

DigitalCommons@University of Nebraska - Lincoln

\title{
Use of Radar Remote Sensing (RADARSAT) to Map Winter Wetland Habitat for Shorebirds in an Agricultural Landscape
}

Oriane W. Taft

U.S. Geological Survey, oriane_taft@usgs.gov

Susan M. Haig

U.S. Geological Survey, Susan_Haig@usgs.gov

Chris Kiilsgaard

Northwest Habitat Institute

Follow this and additional works at: https://digitalcommons.unl.edu/usgsstaffpub

Taft, Oriane W.; Haig, Susan M.; and Kiilsgaard, Chris, "Use of Radar Remote Sensing (RADARSAT) to Map Winter Wetland Habitat for Shorebirds in an Agricultural Landscape" (2004). USGS Staff -- Published Research. 676.

https://digitalcommons.unl.edu/usgsstaffpub/676

This Article is brought to you for free and open access by the US Geological Survey at DigitalCommons@University of Nebraska - Lincoln. It has been accepted for inclusion in USGS Staff -- Published Research by an authorized administrator of DigitalCommons@University of Nebraska - Lincoln. 


\section{Use of Radar Remote Sensing (RADARSAT) to Map Winter Wetland Habitat for Shorebirds in an Agricultural Landscape}

\author{
ORIANE W. TAFT*,† \\ SUSAN M. HAIG \\ USGS Forest and Rangeland Ecosystem Science Center \\ 3200 SW Jefferson Way \\ Corvallis, Oregon 97331, USA
}

\author{
CHRIS KIILSGAARD \\ Northwest Habitat Institute \\ P.O. Box 855 \\ Corvallis, Oregon 97339, USA
}

ABSTRACT / Many of today's agricultural landscapes once held vast amounts of wetland habitat for waterbirds and other wildlife. Successful restoration of these landscapes relies on access to accurate maps of the wetlands that remain. We used C-band (5.6-cm-wavelength), $\mathrm{HH}$-polarized radar remote sensing (RADARSAT) at a $38^{\circ}$ incidence angle (8-m resolution) to map the distribution of winter shorebird (Charadriiformes) habitat on agricultural lands in the Willamette Valley of western Oregon. We acquired imagery on three dates (10 De- cember 1999, 27 January 2000, and 15 March 2000) and simultaneously collected ground reference data to classify radar signatures and evaluate map accuracy of four habitat classes: (1) wet with $\leq 50 \%$ vegetation (considered optimal shorebird habitat), (2) wet with $>50 \%$ vegetation, (3) dry with $\leq 50 \%$ vegetation, and (4) dry with $>50 \%$ vegetation. Overall accuracy varied from 45 to $60 \%$ among the three images, but the accuracy of focal class 1 was greater, ranging from 72 to $80 \%$. Class 4 coverage was stable and dominated maps (40\% of mapped study area) for all three dates, while coverage of class 3 decreased slightly throughout the study period. Among wet classes, class 1 was most abundant (about 30\% coverage) in December and January, decreasing in March to approximately $15 \%$. Conversely, class 2 increased dramatically from January to March, likely due to transition from class 1 as vegetation grew. This approach was successful in detecting optimal habitat for shorebirds on agricultural lands. For modest classification schemes, radar remote sensing is a valuable option for wetland mapping in areas where cloud cover is persistent.
Wetlands have received worldwide recognition in the last few decades, especially in light of their alarming loss and significant value to society. Western settlement and agricultural conversion are responsible for the vast majority of the estimated $53 \%$ loss of wetlands in the lower 48 US states (Dahl 1990, Mitsch and Gosselink 2000). In the Pacific West, statewide losses are estimated at $31 \%$ for Washington, 38\% for Oregon, and $91 \%$ for California (Dahl 1990) and local losses for estuaries and river basins range from 50 to $95 \%$ (Akins 1970, Dennis and Marcus 1984, Boulé and Bierly 1987). Wetland loss has been no less severe for one wetland region in the Pacific Northwest-the Willamette Valley of western Oregon (Taft and Haig 2003). Through

KEY WORDS: Agricultural landscape; RADARSAT; Radar remote sensing; Shorebirds; Wetland habitat mapping; Willamette Valley

Published online June 3, 2003.

*Author to whom correspondence should be addressed, email: Oriane_Taft@usgs.gov

${ }^{\dagger}$ Also, Department of Fisheries and Wildlife, Oregon State University, Corvallis, Oregon 97331, USA modification of river channel morphology and drainage of mesic prairies, the majority of native winter riverine wetlands and wetland prairies that once provided habitat to countless wintering and migrating waterbirds (e.g., waterfowl, wading birds, shorebirds, cranes) has been lost to agriculture. Today, remaining wetlands in the Willamette Valley (Valley) are primarily dispersed among small urban remnant wetlands, a few duck hunting reserves, four larger state and federally protected wildlife refuges, and hundreds of scattered unprotected agricultural wetlands ("palustrine emergent-farmed wetlands" [Cowardin et al. 1979]). The latter represent the legacy of a once vast wetland prairie. With estimates for total native wetland loss/conversion as high as 67\% (Taft and Haig 2003) and continued yearly loss of habitat (Bernert and others 1999), a number of local and federal agencies and coalitions now recognize the urgent need to identify, protect, and restore extant Valley wetlands on a regionwide scale (e.g., Good and Sawyer 1998, Drut and Buchanan 2000, Morlan 2000).

Developing strategic wetland restoration plans on a landscape scale requires a series of maps depicting the 
spatial and temporal distribution of wetland habitats. While the US Fish and Wildlife Service (1991) has completed National Wetlands Inventory (NWI) coverage for the Willamette Valley, these maps portray only Valley wetlands that typically occur during the spring growing season, not during the rainy winter months when wetlands are most prevalent. Other comprehensive Valley mapping efforts were also based on imagery acquired in fall or spring (e.g., Kiilsgaard 1999, Oetter and others 2000). Consequently, the principal type of wetland habitat in the Valley-ephemeral agricultural wetlands- has been entirely overlooked. Because these wetlands hold great potential for restoration, it is essential to understand their spatial distribution and temporal dynamics.

Wetland mapping has undergone considerable advancement in the last two decades as researchers have realized the application potential of various satellite remote sensing techniques. While many sensoring platforms have been used to inventory wetlands for monitoring and regulatory purposes (see Lee and Lunetta 1995), wetland biologists have only recently recognized the value of satellite remote sensing in wetland wildlife conservation. The most prominent application of remote sensing for wetland wildlife conservation has been to map specific habitats important to wetland species on a regional scale (e.g., Wickware and others 1980, Jacobson 1991, Kempka and others 1992, Gratto-Trevor 1996). With auxiliary data on the spatial distribution of individuals and their preferences for different habitats, imagery depicting habitat types can also be used to predict regional distribution or density of a species (e.g., Avery and Haines-Young 1990, Goss-Custard and Yates 1992, Aspinall and Veitch 1993, Morrison 1997, Scott and others 2002). Specialized projects to map particular wetland habitat types are becoming more common as the spatial, temporal, or informational resolution of already existing wetland maps often does not match the needs of wetland wildlife biologists.

Most satellite remote sensors are optical (e.g., Landsat Multispectral Scanner [MSS] and Thematic Mapper [TM], Systeme Pour l'Observation de la Terre [SPOT]), reliant on collecting reflected energy from the Earth's surface at wavelengths in the visible portion of the electromagnetic spectrum (Avery and Berlin 1992, Lee and Lunetta 1995). While these have been used to identify and monitor a variety of wetland types, they exhibit a number of limitations including spectral confusion of wetland and nonwetland categories (Jensen and others 1987, Henderson and others 1999, Bourgeau and others 2001) and, most notably, an in- ability to map land surface during periods of cloud cover (Ramsey 1999). Unlike optical sensors, radar sensors (e.g., satellites ERS-1/2, JERS-1, and RADARSAT) do not rely on cloud-free conditions (Metternicht 1999). These actively transmit energy at microwave frequencies (radar) to produce a black-and-white image from the energy returning to the sensor after interacting with the Earth's surface. Radar sensors can penetrate clouds, rain, and haze commonly encountered during a rainy season. Moreover, radar is particularly effective at detecting boundaries between water and land, flooding, surface roughness, and moisture content of vegetation and soil, depending on parameter settings (Kasischke and others 1997, Elachi 1988, Metternicht 1999, Ramsey 1999). Wetlands used by waterbirds tend to be shallow with open water unobscured by vegetation, and any vegetation present is typically different from that found within other land cover types (Mitsch and Gosselink 2000). Such features structurally contrast them with the surrounding landscape, making them particularly favorable for radar mapping (Ramsey 1999). In areas with a high incidence of rainfall, radar technologies may be useful in mapping standing shallow sheetwater or saturated soil with differing vegetation coverage, conditions common on agricultural wetlands of the Valley.

We recognized the need for a series of maps depicting the typical extent and dynamics of Valley wetlands to aid future restoration efforts. In addition, we had a need for such maps to complete a related project addressing determinants of habitat use by the 40,000 or more Valley wintering shorebirds (order Charadriiformes [Johnson 1993, Nehls 1994, Gilligan and others 1994, Sanzenbacher and Haig 2002a, 2002b, Taft and Haig unpublished data]). Finally, winter cloud cover in the Willamette Valley can be persistent. Thus, using remotely sensed radar (RADARSAT) data, we set out to map winter wetland habitat in the Valley, specifically focusing on agricultural wetland sites frequented by shorebirds. Our specific objectives were (1) to evaluate the utility and accuracy of using $\mathrm{C}$-band $\mathrm{HH}$ polarized radar remote sensing to develop maps of ephemeral wetland habitat (primarily agricultural) important to shorebirds and (2) to produce three winter cover maps (beginning, middle, and end of winter) identifying wet (either impounded water or shallow sheetwater/saturated soil), unvegetated ( $\leq 50 \%$ cover) wetland areas used by shorebirds and other waterbirds. In addition, this paper provides examples of potential uses of our maps and suggests possible approaches for improving radar performance for this particular application. 


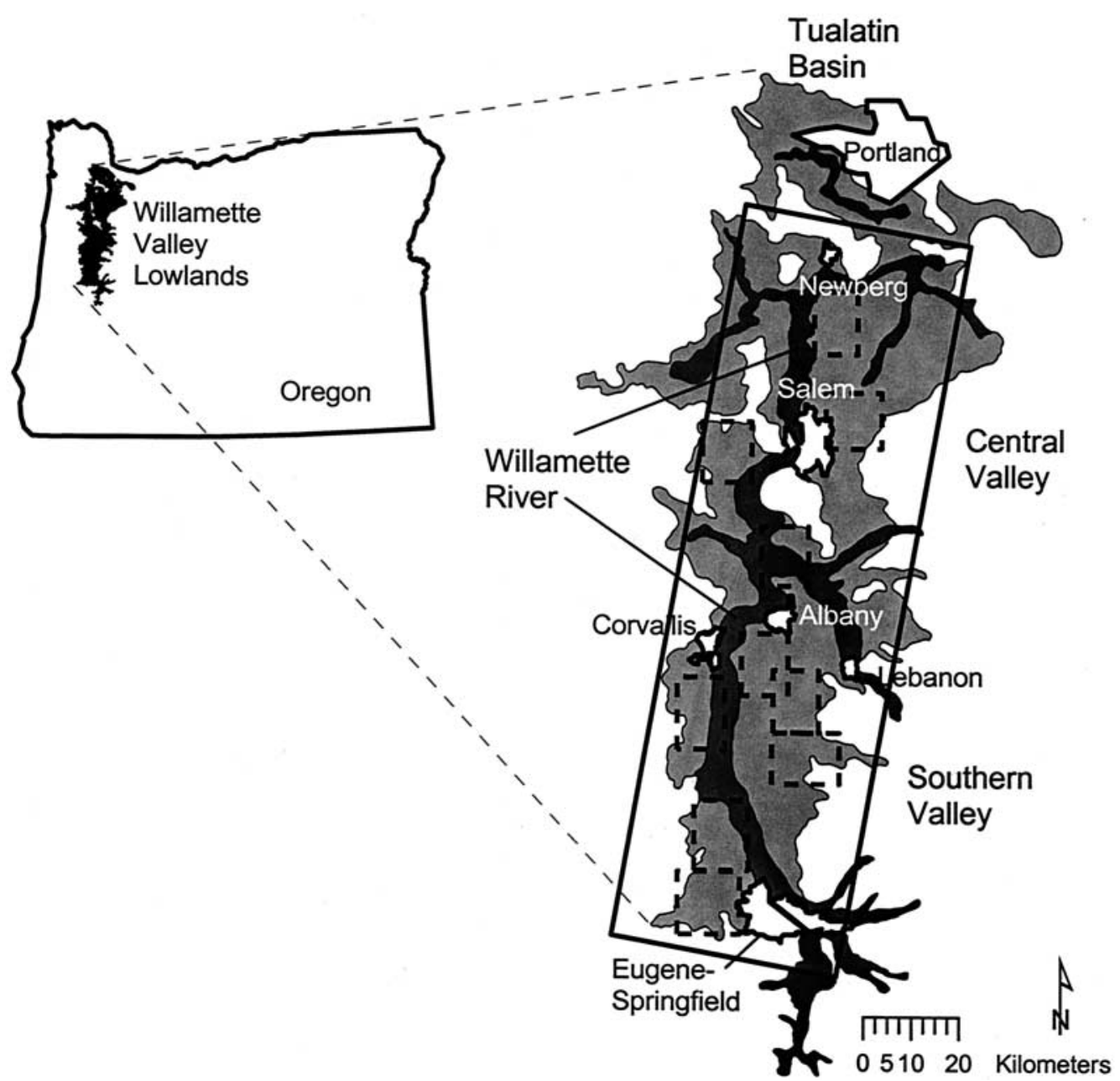

Figure 1. The Willamette Valley of western Oregon, including the area covered by radar imagery (large rectangle) and 10 areas of focus for ground reference data collection (small dashed rectangles). The two lowland subecoregions are highlighted in light gray (Prairie Terraces) and dark gray (Willamette River and Tributaries Gallery Forest).

\section{Study Area}

Within the Willamette Basin of western Oregon, the Valley encompasses a $9100-\mathrm{km}^{2}$ area of lowland plains (including the "Prairie Terraces" and "Willamette River and Tributaries Gallery Forest" subecoregions but excluding the "Valley Foothills" [Clark and others 1991, Pater and others 1997]) varying in width from about 20 to $60 \mathrm{~km}$ and covering a north-south length from Portland to Eugene of roughly $290 \mathrm{~km}$ (Figure 1) (Benner and Sedell 1997, Hulse and others 1998). The prominent hydrologic feature of the Valley is the northerly flowing Willamette River and its 13 major tributaries, which together drain the Willamette Basin, a 29,000- $\mathrm{km}^{2}$ watershed between the Cascade and the Coast ranges of Oregon (Oetter and others 2000). The climate of this region is considered cool Mediterranean
(Jackson and Kimerling 1993), with an average annual rainfall of 100-125 cm and average temperatures ranging from $1{ }^{\circ} \mathrm{C}$ in January to $30^{\circ} \mathrm{C}$ in July (Oetter and others 2000).

Our map study area included the central and southern regions of the Valley but excluded the Tualatin basin (Figure 1). General landforms in the Valley include alluvial terraces and floodplains interrupted by basalt outcrops and gently sloping hills of both volcanic and sedimentary origin (Oetter and others 2000). The majority of the Valley is dominated by agriculture, primarily grass seed fields on the alluvial terraces. Other common lowland crops include vegetable crops, fruit orchards, nursery and greenhouse stock, and peppermint (Hulse and others 1998, Oetter and others 2000). Grass seed crops and peppermint are planted in the fall on plowed, leveled barren fields. While annual ryegrass 

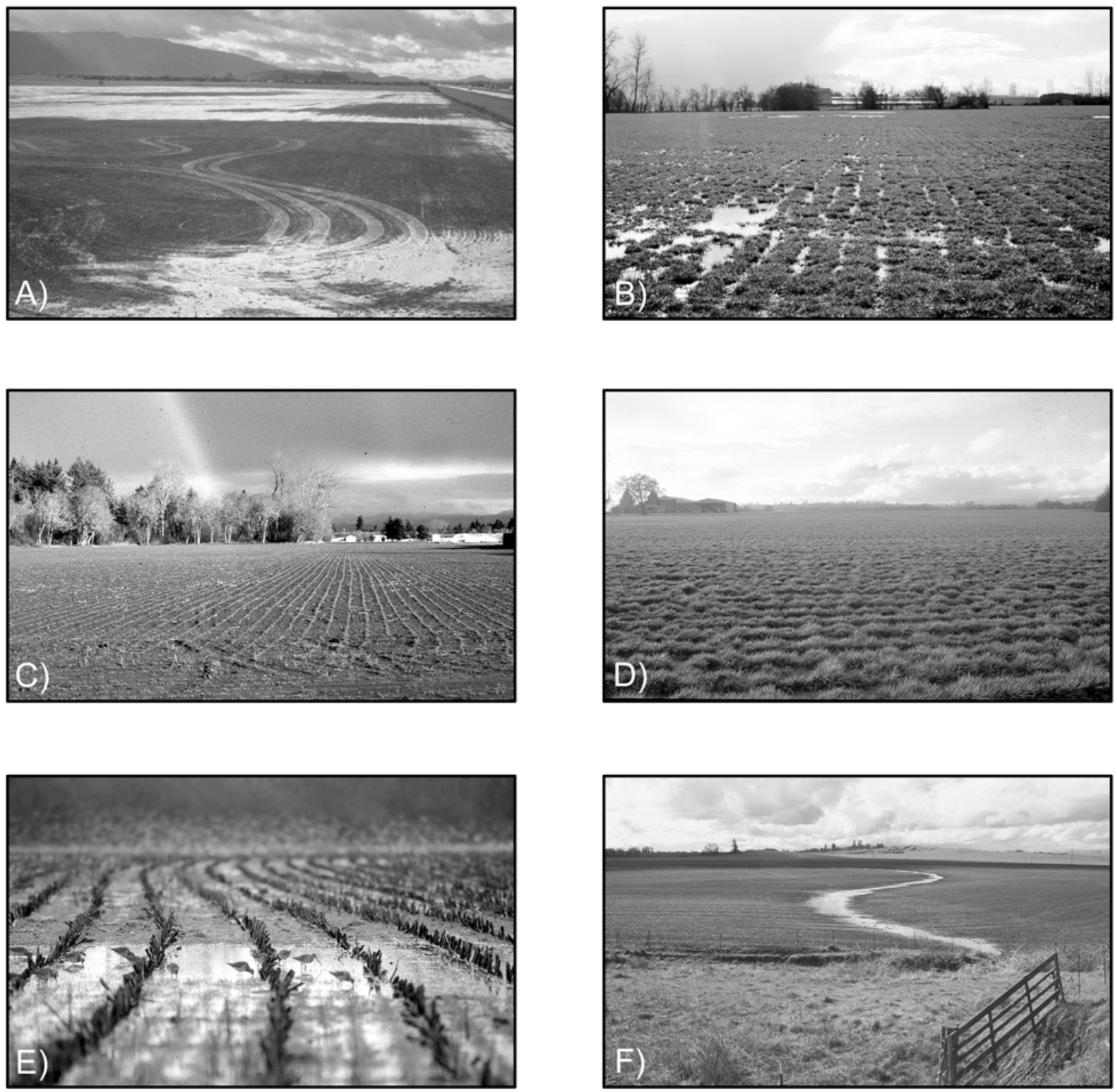

Figure 2. Photographs exemplifying typical habitat in the four classes mapped with radar (RADARSAT) remote sensing in the Willamette Valley of Oregon during winter 1999-2000: (A) class 1, optimal shorebird habitat—wet, $\leq 50 \%$ vegetation; (B) class 2 -wet, $>50 \%$ vegetation; (C) class $3-$ dry, $\leq 50 \%$ vegetation; (D) class $4-$ dry, $>50 \%$ vegetation. Additional photos of class 1 are shown in (E) a flooded fallow cornfield with foraging long-billed dowitchers (Limnodromus scolopaceus) and (F) a linear agricultural wetland/remnant slough in a newly planted grass field; many of these were not mapped if less than about 3 8-m pixels (25 m) wide.

is replanted every year, perennial ryegrass is generally replanted on a 3-year cycle. Vegetable crops are annually plowed in fall and left fallow through the winter. By spring (March), annual grass fields are fully covered with vegetation, while perennial grass fields still provide exposed soil between plants. These agricultural fields potentially hold water in winter where hydric soils pre- dominate (Figure 2). Common wintering shorebirds in the Valley include dunlin (Calidris alpina), killdeer (Charadrius vociferus), common snipe (Gallinago gallinago), long-billed dowitcher (Limnodromus scolopaceus), black-bellied plover (Pluvialis squatarola), greater yellowlegs (Tringa melanoleuca), and least sandpiper (Calidris minutilla). 


\section{Methods}

\section{Classification Scheme}

During the winter of 1998-1999, we conducted a preliminary study on the agricultural habitat associations of Dunlin and Killdeer, the two most abundant wintering shorebirds in the Valley. Roughly $90 \%$ of fields used by dunlin were flooded with shallow $(<$ 5-cm-deep) water and/or had saturated soil. About $70 \%$ were covered with less than $50 \%$ vegetation. In contrast, killdeer were more of a wetland generalist; only $50 \%$ of used fields held standing water/saturated soil and $55 \%$ had less than $50 \%$ vegetative cover. Thus, in mapping shorebird habitat on agricultural lands, we focused on identifying flooded fields with exposed soil (less than 50\% cover; Figure 2E); these conditions are preferred by dunlin and ecological allies (species in the family Scolopacidae). We designed a classification scheme of four classes based on the presence of water and vegetation (Figure 2): (1) wet (either impounded water or shallowly flooded) with $\leq 50 \%$ vegetation, (2) wet with $>50 \%$ vegetation, (3) dry (without visible standing water) with $\leq 50 \%$ vegetation, and (4) dry with $>50 \%$ vegetation. We considered habitat to increase in suitability for shorebirds from the highest class number to the lowest, with class 1 regarded as optimal.

\section{Imagery and Preprocessing}

We acquired imagery on 3 selected days when the Canadian RADARSAT satellite passed over the Valley study area: 10 December 1999, 27 January 2000, and 15 March 2000. Scene acquisition dates were 48 days apart, or on every other 24-day orbit pass. With these dates we aimed to capture the extent of shorebird wetland habitat at three time periods: at the onset of early winter rainfall (early December), at the peak of the midwinter rainy season (January), and during waning rain activity in late winter/early spring (March).

The RADARSAT satellite carries a C-band (5.6-cmwavelength) synthetic aperture radar (SAR) with $\mathrm{HH}$ (horizontally transmitted/horizontally received) wavelength polarization (Corbley 1995). All scenes were taken in fine 1 far $(\mathrm{F} 1 \mathrm{~F})$ beam mode (8-meter pixel resolution, $38.78^{\circ}$ incidence angle) on descending orbits at $1418 \mathrm{hr}$. There is a trade-off between pixel resolution and features one can detect with particular incidence angles. Soil moisture and water under grass canopies are best detected at steep incidence angles $(<$ $30^{\circ}$ ) to nadir (Elachi 1988, Ramsey 1995, Biftu and Gan 1999), but RADARSAT imagery at these angles is available only at resolutions of $25 \mathrm{~m}$ or greater. Images at 8-m resolution are acquired at larger angles. We chose
F1F imagery because we were most interested in detecting standing water in open habitat and because we needed the finest resolution possible to detect small patches of standing water. Scenes at F1F are approximately $50 \times 50 \mathrm{~km}$, thus it took three scenes to cover our focal study area (central and southern Valley) on each acquisition date. These images were aligned and acquired north-south so that each final map, once mosaicked, would continuously cover an area of roughly $50 \times 150 \mathrm{~km}\left(4500 \mathrm{~km}^{2}\right)$, encompassing Valley lowlands in the two subecoregions of interest (Prairie Terraces and Willamette River and Tributaries Gallery Forest [Pater and others 1997]) from Eugene to Newberg, Oregon (Figure 1). We used Pater and others (1997) to mask the Valley Foothills subecoregion from radar imagery acquired in the $50 \times 150-\mathrm{km}$ swath. Thus, the size of the study area portrayed by final maps was $4209 \mathrm{~km}^{2}$.

Before rectifying scenes, we used Sigma and Lee filters to reduce speckle noise (Rio and others 2000). Among nine scenes, we were able to reduce coefficients of variation for noise from $0.387-0.399$ at raw imagery to $0.213-0.223$ at the second pass. We then rectified all December scenes to a 1996 Landsat Thematic Mapper reference image of the Valley. Among the three December scenes, we selected between 18 and 34 ground control points (GCPs) to calculate third-order polynomial transformations used to georegister input images to the reference scene. Among the three scenes, registration was achieved with an error of 22-28 m, approximately the size of a Landsat TM pixel $(30 \mathrm{~m})$. Scenes for January (using 41-52 GCPs) and March (38-45 GCPs) were georegistered to the rectified December scenes, also using third-order polynomial transformations. Registration errors were lower among these six scenes, ranging from 4.8 to $16.7 \mathrm{~m}$. We used a cubic convolution resampling procedure to assign new coordinate grids to scenes. After georegistration, the three scenes for each date were mosaicked into composite images used in the classification effort.

\section{Ground Reference Data Collection}

For classification and verification, we collected ground reference data from roadsides and aerial flights within 1-2 days of each image acquisition date. Topography of the Valley alluvial terraces is strikingly flat $(<$ $1^{\circ}$ slope), with maximum elevation fluctuations of the order of only meters over a horizontal distance of $10-$ $100 \mathrm{~km}$ (Hulse and others 1998). As a result, within individual agricultural fields, surface water tends to accumulate into numerous discrete small (of the order of decameters) shallow ponds (less than $25 \mathrm{~cm}$ deep) or as diffuse and widespread "sheetwater" (shallow, 1-cm- 
deep water spread across a flat surface; Figure 2). Such spatial patterning logistically precluded determining the exact coordinate locations of the boundaries of all individual water bodies. Instead, we considered reference "sites" as entire agricultural fields if they were homogeneous in wetness and cover, or as wet areas within otherwise dry fields (e.g., a large pond, a remnant slough). We could not feasibly quantify soil moisture, water depth, surface roughness, or percentage cover of vegetation. Thus, we categorized sites into habitat classes by qualitatively noting the presence and prominence of surface water and visually estimating the percentage cover of vegetation as $\leq 50 \%$ or $>50 \%$. We did not separately distinguish habitat with saturated soil (showing a glossy sheen but without standing water) from habitat with sheetwater because they almost always cooccur on a fine spatial scale (meters) within fields.

We selected ground reference sites opportunistically by traversing roads and taking aerial photos in areas with a high incidence of hydric soils (Daggett and others 1998). For both modes of data collection, we focused on finding wet, unvegetated sites (class 1, optimal shorebird habitat). Sites in all other classes were interspersed within these areas. We documented a total of 689 reference sites for the December image, 731 for January, and 592 for March. Sites were fairly well interspersed among classes, but wet classes were better represented. We selected sites in the north and south Valley interspersed among 10 focal areas (Figure 1), but due to the concentrated nature of hydric soils, sites within these areas were locally clustered. For January and March referencing, we revisited a large proportion of sites we had visited in December to assess temporal changes.

For roadside-collected data, we located reference sites by estimating the distance and direction to the focal site of interest from a GPS- or landmark-located roadside position (e.g., crossroad). During January and March, we used a laptop computer displaying the December raw imagery and a road layer overlay to mark location of sites concurrently while in the field. We digitized sites by looking for pixels of uniform radar returns in the close vicinity of estimated locations and then assigning the site's positional coordinate to a central pixel for each cluster. To aid analyses and temporal comparisons, one or more photos were taken of each roadside site during each of the three dates.

For data collected aerially (in a Cessna 182RG), we took oblique photos of the landscape at an elevation of approximately $450 \mathrm{~m}$ and used visible roads and landmarks to find the coordinate location of focal sites. Because vegetative cover was often difficult to estimate by air, we used aerial photos only to find sites with very little $(<10 \%)$ vegetation (class 1$)$. Wet fields were obvious because sheetwater/saturated soil appeared glossy and dark from the air.

\section{Image Analysis and Final Maps}

We used both supervised and unsupervised classification techniques to associate spectral signature with habitat classes. Using our field data, we were able to distinguish a specific signature to supervise the classification of class 1 habitat only; we used unsupervised training to produce signatures for the remaining classes. For supervised classification of habitat in class 1 , we delineated polygons around pixel clusters of homogeneous spectral returns within class 1 reference sites and calculated mean, standard deviation, minimum and maximum digital values for all pixels within each polygon. We then used a maximum likelihood classification algorithm to delineate class 1 habitat within mosaicked scenes. To classify habitat in classes $2-4$, we separated returns remaining in the class 1-masked scene into 50 distinct spectral clusters. We chose the number 50 to accommodate the variability of signatures we expected from the myriad of permutations of wet and dry soils with varying amounts of vegetation. Using roughly half of our ground reference data set (415 sites from December, 448 sites from January, and 308 sites from March) as training sites (randomly chosen), we then visually determined which of the three categories each of the 50 return clusters represented and recoded the 50 clusters into three remaining habitat classes. Finally, we overlaid each of the final classified mosaicked images with urban, forest, and permanent open water (reservoirs, rivers, etc.) land cover using an ancillary map developed from 1996 Landsat TM imagery (Kiilsgaard 1999).

\section{Accuracy Assessment}

We assessed the accuracy of final maps using the remaining ground reference sites not used for training; this resulted in 274 verification sites for December, 283 for January, and 284 for March. For each site, we compared its predicted class from final maps to the site's true class and constructed an error matrix of these comparisons for each date. The error assessment characterized the accuracy of each map, with commission error or "user's accuracy" (proportion of sites assigned to a class that are correctly assigned) and omission error or "producer's accuracy" (the proportion of sites of a certain class that are correctly assigned) included. For each map, we calculated overall accuracy as the number of correctly classified sites divided by the total number of testing sites. 


\section{Results}

\section{Spatial and Temporal Patterns}

Among all three maps, the majority of the $4209-\mathrm{km}^{2}$ study area was categorized as class 4 (Figure 3), with roughly $40 \%$ coverage (Figure 4 ). For the December and January maps, class 1 was the next most abundant class predicted ( $\sim 30 \%$ of the study area) and class 2 was the least prevalent, at about $10 \%$ coverage. Moreover, optimal shorebird habitat (class 1) was generally dispersed throughout the entire study area. However, concentrations in the southern Valley occurred between Albany and Lebanon and southward, and west of the Willamette River between Corvallis and Eugene (Figure 3). There were also coalesced patches of class 1 habitat around Independence. In the central Valley, class 1 habitat was most prevalent west and northeast of Salem and west of Woodburn.

Overall, winter 1999-2000 was an average season in rainfall, but precipitation varied across months. Monthly precipitation totals for Corvallis, Oregon, were as follows: November $(23 \mathrm{~cm}$; 6-cm departure from the 1961-1990 average), December (15 cm; -5 -cm departure), January (20 cm; 3-cm departure), February (16 cm; 3-cm departure), and March (9 cm; -2-cm departure [Oregon Climate Service 1999-2000]). Covering roughly $30 \%$ of the study area, optimal shorebird habitat (class 1) was more prevalent in December and January (slightly more in January) than in March (Figure 4). Although optimal habitat decreased in March, class 2 habitat increased, retaining the same proportion (40\%) of wet habitat (classes 1 and 2 combined) across dates despite monthly variation in rainfall. Likewise, slight declines in coverage of class 3 were mirrored by small increases in class 4 across dates. Estimates for total coverage of wet classes should be viewed with caution, however, as class 2 accuracies were fairly low (see below). The declines in classes 1 and 3 and corresponding increases in classes 2 and 4 may be partially explained by the steady growth of agricultural vegetation. Between January and March, many sites transitioned from class 1 to class 2 or from class 3 to class 4 .

\section{Radar Signatures and Map Accuracy}

Among flooded habitat, radar returns for open water found on refuge impoundments, riceponds, and shallow reservoirs (weak return, black image tones) were similar to returns from shallow sheetwater/saturated soil on unvegetated fields (weak return, dark-gray image tones). We considered both signatures to display "wet" habitat. Vegetated sites with either a wet or a dry substrate under grass canopies gave a brighter return (strong return, lighter-gray tones) than unvegetated habitat. Radar returns from dry, unvegetated sites were darker relative to vegetated sites but brighter (lighter in tone) relative to wet sites.

The error matrix for each map indicates an overall accuracy of $60 \%$ for December, $59 \%$ for January, and $45 \%$ for March (Table 1). By pooling cover types into only two classes for wetness-wet and dry-the overall map accuracy increased to $78 \%$ for December, $78 \%$ for January, and $75 \%$ for March. Pooling cover types into two classes for vegetation- $\leq 50 \%$ vegetation and $>$ $50 \%$ vegetation-overall map accuracies were $72 \%$ for December, $69 \%$ for January, and $57 \%$ for March. For all classification schemes, map accuracy diminished between January and March.

Among the four classes, class 1 (wet, $\leq 50 \%$ vegetation) was most accurately mapped, with user's accuracy for all three maps between 72 and $80 \%$ (Table 1). Producer's accuracy was also fairly high in December (83\% accuracy) and January (76\%). The low producer's accuracy (47\%) in March was due primarily to class 1 sites being confused for class $2(57 / 175$ sites) and class 4 (25/175 sites).

Classes 2-4 did not map as accurately as class 1 . For all three maps, sites of class 2 (wet, $>50 \%$ vegetation) were highly misclassified, commonly confused for class 1 or class 4 (Table 1 ). Class 3 (dry, $\leq 50 \%$ vegetation) was regularly misidentified as class 1 in December and as class 4 in January and March. In general, class 4 (dry, $>50 \%$ vegetation) was moderately confused with each of the other three classes, but especially class 1 . The lower user's than producer's accuracy for most classes (Table 1) indicates that commission errors tended to be more prevalent than omission errors.

\section{Discussion}

Radar remote sensing proved to be an effective and valuable tool for mapping habitat important to shorebirds on agricultural lands in winter. Final maps revealed far more shorebird/wetland habitat than was previously thought to exist in the Valley during winter, pointing to the importance of including agricultural habitat in regional restoration and conservation plans. Our error assessments support the notion that singleparameter radar imagery is useful for modest wetland classification schemes (Lee and Lunetta 1995). Moreover, success depends on the number of classes that one hopes to depict accurately. Among classes, we were most interested in mapping the distribution of optimal shorebird habitat, or land in class 1 (wet, $\leq 50 \%$ vegetation). While the overall map accuracy was fairly low (45-60\%) for each date, the user's accuracy of class 1 was appreciably higher (72-80\%). The accuracy of wet 

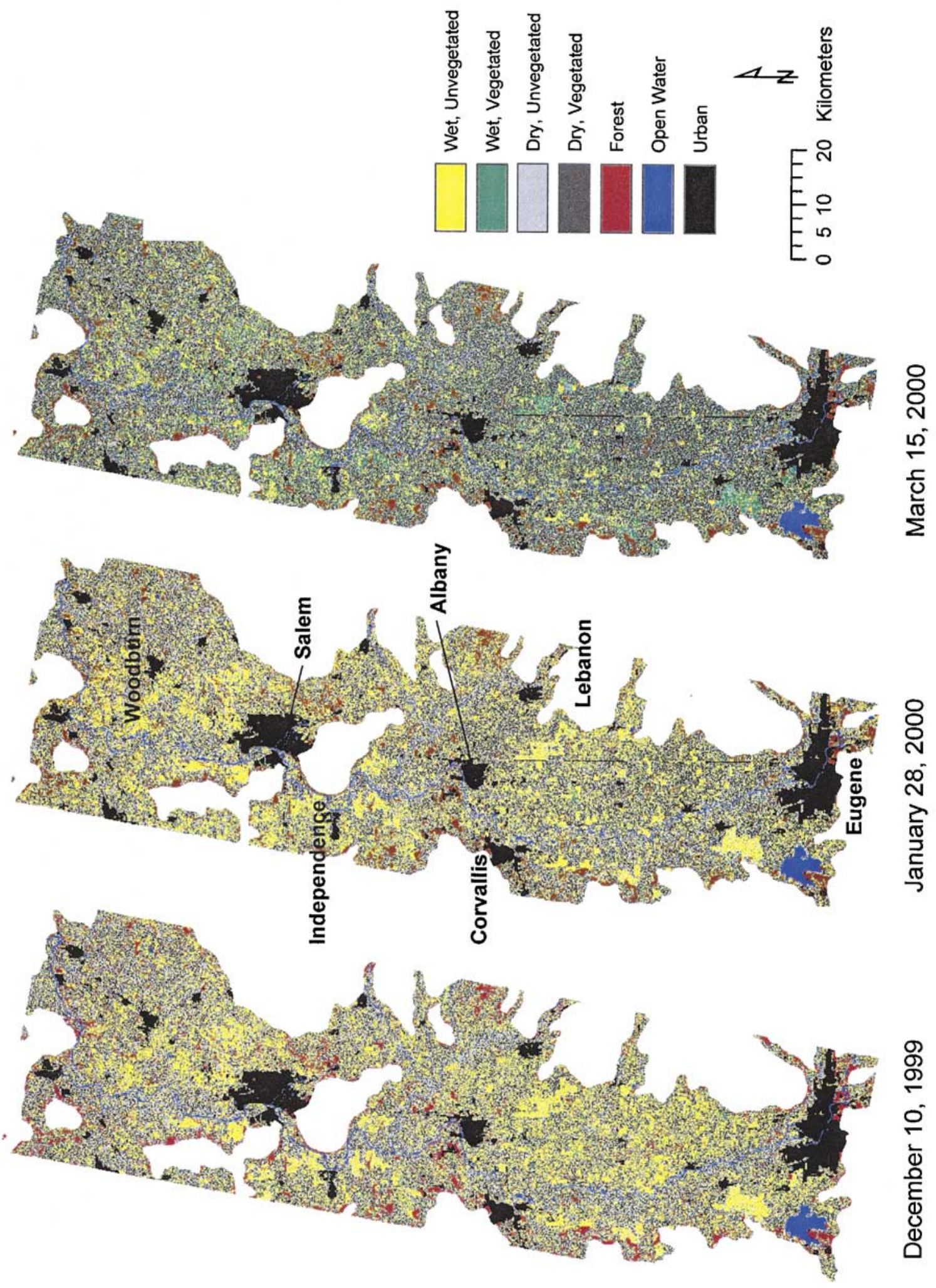

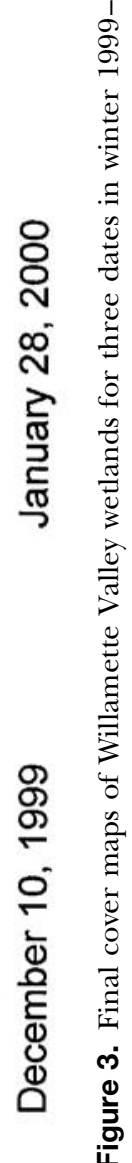




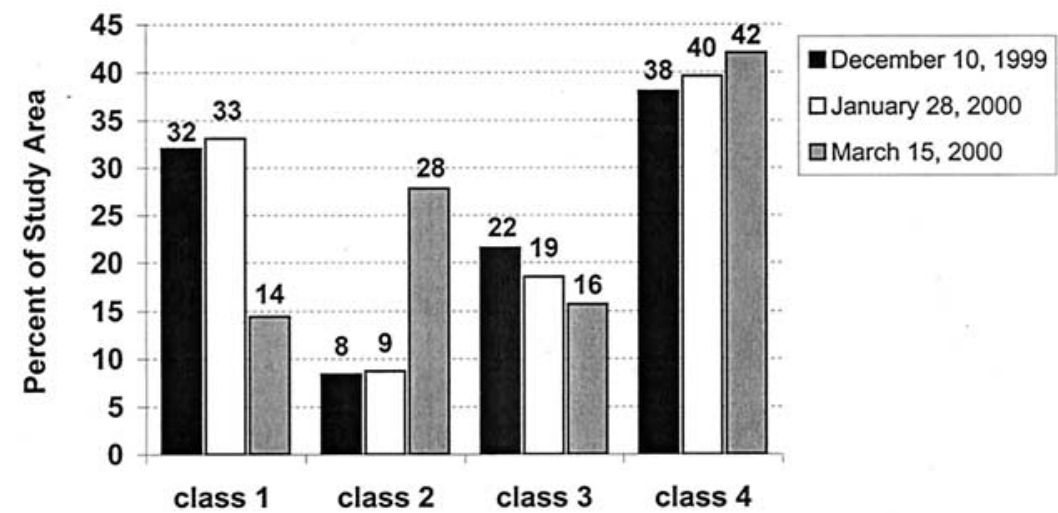

Figure 4. Temporal changes in percentage cover (of the entire Willamette Valley map study area) of four land cover classes across the three image dates during the winter of 1999-2000. Class 1, optimal shorebird habitat-wet, $\leq 50 \%$ vegetation; class 2-wet, $>50 \%$ vegetation; class 3 - dry, $\leq 50 \%$ vegetation; class 4-dry, $>50 \%$ vegetation.

Table 1. Error matrix for final wetland maps of the Willamette Valley, Oregon ${ }^{a}$

\begin{tabular}{|c|c|c|c|c|c|c|}
\hline \multirow[b]{2}{*}{ Map prediction } & \multicolumn{5}{|c|}{ Reference } & \multirow[b]{2}{*}{ User's accuracy $(\%$} \\
\hline & Class 1 & Class 2 & Class 3 & Class 4 & Total & \\
\hline \multicolumn{7}{|c|}{ Class 1: wet, $\leq 50 \%$ vegetation } \\
\hline 10 Dec. & 135 & 33 & 8 & 11 & 187 & 72 \\
\hline 27 Jan. & 130 & 33 & 4 & 14 & 181 & 72 \\
\hline 15 Mar. & 82 & 14 & 3 & 4 & 103 & 80 \\
\hline \multicolumn{7}{|c|}{ Class 2: wet, $>50 \%$ vegetation } \\
\hline 10 Dec. & 6 & 9 & 1 & 2 & 18 & 50 \\
\hline $27 \mathrm{Jan}$. & 11 & 10 & 0 & 1 & 22 & 45 \\
\hline 15 Mar. & 57 & 22 & 6 & 4 & 89 & 25 \\
\hline \multicolumn{7}{|c|}{ Class 3: dry, $\leq 50 \%$ vegetation } \\
\hline 10 Dec. & 9 & 3 & 11 & 7 & 30 & 37 \\
\hline $27 \mathrm{Jan}$. & 10 & 2 & 12 & 0 & 24 & 50 \\
\hline 15 Mar. & 11 & 4 & 9 & 6 & 30 & 30 \\
\hline \multicolumn{7}{|c|}{ Class $4:$ dry, $>50 \%$ vegetation } \\
\hline 10 Dec. & 13 & 13 & 3 & 10 & 39 & 26 \\
\hline $27 \mathrm{Jan}$. & 21 & 11 & 8 & 16 & 56 & 29 \\
\hline 15 Mar. & 25 & 15 & 7 & 15 & 62 & 24 \\
\hline \multicolumn{7}{|l|}{ Total } \\
\hline 10 Dec. & 163 & 58 & 23 & 30 & 274 & \\
\hline $27 \mathrm{Jan}$. & 172 & 56 & 24 & 31 & 283 & \\
\hline 15 Mar. & 175 & 55 & 25 & 29 & 284 & \\
\hline \multicolumn{7}{|c|}{ Producer's accuracy (\%) } \\
\hline 10 Dec. & 83 & 16 & 48 & 33 & & 60 \\
\hline $27 \mathrm{Jan}$. & 76 & 18 & 50 & 52 & & 59 \\
\hline 15 Mar. & 47 & 40 & 36 & 52 & & 45 \\
\hline
\end{tabular}

${ }^{a}$ Numbers on the diagonal (boldface) are reference sites correctly classified, whereas those off the diagonal signify reference sites (columns) incorrectly predicted in each class (rows). Row totals signify the total number of sites predicted in each class, whereas column totals signify the true total number of sites in each class used in the analysis.

habitat was further supported by visually assessing the spatial correspondence of hydric soils (Daggett and others 1998) with the distribution of classes 1 and 2. Considering class 1 as optimal shorebird habitat interspersed in a matrix of suboptimal habitat (classes 2-4), the accuracy of class 1 habitat was the most meaningful measure for map accuracy.

Some of the map error likely stems from interactions between ground features (land/water boundaries, sur- face roughness, moisture content) and radar parameter configurations (incidence angle, wavelength, and polarization). These interactions are highly complex and the subject of much research (Lee and Lunetta 1995, Metternicht 1999, Ramsey 1999). First, a given surface will increase in specular reflectance (appear smoother) with larger incidence angles (Avery and Berlin 1992, Sokol and others 2000). Thus, our relatively large incidence angle may have been the source of some error in 
the confusion of vegetated (class 2 and 4) land cover for wet, unvegetated (class 1) cover, especially habitat with close to $50 \%$ vegetation (i.e., 40-60\%). Second, detecting water under a grass canopy requires a radar beam emitted at a steep incidence angle $\left(<30^{\circ}\right)$ or with a long wavelength (Ormsby and others 1985, Ramsey 1995, Wang and others 1995). RADARSAT's shallow incidence angle combined with the short wavelength suggests lessened penetration through grass canopies and thus less of a return from flooded vegetated ground (Ramsey 1995, 1999). This may account for confusion among vegetated wet (class 2) and dry (class 4) sites. Third, RADARSAT's polarization may have been another source of error. Sensors with $\mathrm{HH}$ polarization are known to be less sensitive to changes in vegetation moisture, content than are cross-polarized sensors (HV or VH [Avery and Berlin 1992]). This may provide an additional explanation for confusion between class 1 and class 2, as moisture in the vegetation of class 2 sites may not have been detected.

Other errors may have been caused simply by similarities among signatures. For example, grass crops of high biomass and homogeneous in horizontal cover and vertical height (e.g., rice, annual ryegrass) tend to act like a smooth surface (similar to calm standing water), decreasing radar returns (Durden and others 1995, Dobson and others 1996). Many of the annual ryegrass sites in class 4 (dry, vegetated) may have been confused for class 1 (wet, unvegetated) for this reason. Moreover, the confusion of class 1 sites for class 2 in March may be explained by the fact that many class 1 sites had grown to nearly $50 \%$ cover by the third date of imagery.

Had we not chosen to use imagery with the finest resolution from one sensor (RADARSAT), different parameter settings or the use of setting combinations from multiple sensors may have improved mapping performance for nonfocal habitats (classes 2-4). While some settings are predetermined by the RADARSAT sensor (i.e., wavelength and wavelength polarization), others are adaptable to user needs (i.e., incidence angle and associated resolution). Choice of a smaller incidence angle may have lessened confusion between vegetated and unvegetated classes and/or enabled penetration through grass canopies to distinguish vegetated areas with understory flooding. Similarly, a steeper incidence angle could have been used had detecting differences in soil moisture been our main objective (Dobson and others 1995). Additionally, because backscatter returns vary with all three radar parameters, the use of multi-incidence angle, multi-wavelength, or multipolarization imagery (e.g., (Wang and others 1995, Dobson and others 1996, Bourgeau-
Chavez and others 2001) may have provided a greater breadth of information for image interpretation (Hess and Melack 1994, Metternicht 1999). For example, by cross-referencing RADARSAT data at multiple incidence angles (e.g., steep 25-m resolution and shallow 8-m resolution), one may be able to produce a map depicting small bodies of standing water while also portraying more information about soil moisture. Multiwavelength and multipolarization imagery would require use of two different radar sensors.

Compared to other radar studies, our SAR data performed well in mapping Valley wetlands. Radar satellite sensors have been used to detect coastal wetlands (e.g., (Henderson and others 1998, Dwivedi and others 1999), tidal flooding (e.g., Ramsey 1995), freshwater wetlands (e.g., Kasischke and Bourgeau-Chavez 1997), forested wetlands (e.g., Hess and Melack 1994, Bourgeau-Chavez and others 2001), forested and unforested peat bogs and marshes (e.g., Baghdadi and others 2001), and soil moisture (e.g., Dobson and others 1995, Biftu and Gan 1999). However, much of this work has focused on the relationships between radar backscatter returns and particular wetland properties (e.g., flooding, soil moisture), rather than on documenting the accuracy of maps created using these relationships. Of the few studies that have documented accuracy, success has been variable. For example, Baghdadi and others (2001) defined six cover types (forested and nonforested peat bog, marsh, open water, clearing, and forest) from variable radar signatures using ERS-1 C-band SAR at different polarizations. For one season, they reported a high overall accuracy of $86 \%$ for cross-polarized data and $76 \%$ for $\mathrm{HH}$ polarization. In contrast, Henderson and others (1998) examined variation in classification accuracy among ERS and RADARSAT images acquired with various incidence angles and polarizations. They classified coastal wetlands into four classes: estuarine emergent, palustrine emergent, palustrine scrub shrub, and palustrine forested wetland. Accuracy was extremely poor for both sensors and all settings, with $17 \%$ the highest accuracy achieved for any one class. In comparison to these, our results are encouraging. The high accuracies found by Baghdadi and others (2001) are partly a function of extreme structural differences among the classes they set out to classify, while high error rates found by Henderson and others (1998) stem from complex, easily confused wetland classes (i.e., all of their classes have some kind of flooding and vegetative cover). In contrast to these two studies, our classification scheme was modest, with classes distinct enough to yield sufficient accuracy with the parameter settings we chose. 
Among wetland mapping projects that depict waterbird habitat, most have been able to use optical remote sensors (e.g., Avery and Haines-Young 1990, Jacobsen 1991, Gratto-Trevor 1996, Morrison 1997). For singlepass imagery, optical sensors (particularly Landsat TM) generally still outperform radar sensors in classification accuracy (e.g., Jensen and others 1993, Gratto-Trevor 1996, Morrison 1997, Henderson and others 1998, Fuller and others 1998, Lunetta and Balogh 1999). Moreover, augmenting radar data with optical imagery will result in the greatest accuracies for wetland maps (Place 1985, Ramsey and others 1998, Pietroniro and others 2000, Töyrä and others 2001). However, for studies where cloud cover can be prevalent, using an optical sensor is seldom an option. Radar imagery enables mapping important waterbird habitat when it otherwise would not be possible, particularly in regions with persistent cloud cover such as Oregon's Willamette Valley in winter.

Our Valley wetland maps hold promise for a number of local applications. First, the spatial distribution of extensive drainage tiling on hydric soil farmlands in the Valley is poorly documented. Hydric soils maps are not always indicative of where ponding will occur. Using our maps, restorationists can now evaluate which general areas of the Valley would be most optimal for restoration efforts. Additionally, information on the location and dynamics of class 1 habitat at local spatial scales may be useful to resource agencies or watershed councils involved in local restoration in the Valley. Finally, these maps enable examining important questions in landscape ecology that are relevant to restoration and management (e.g., Turner 1989, Scott and others 2002), namely, investigating the influence of the spatial and temporal patterning of habitat on the distribution, abundance, and movements of wetland species in the Valley. With spatially continuous data, one can ask these questions at multiple spatial scales pertinent to the species of interest.

Although class 1 habitat invariably includes many wetlands already identified by the National Wetlands Inventory, much of it depicts agricultural wetlands that were unidentified prior to this study. Thus, by illustrating the great extent of winter wetlands on agricultural land, these maps represent a significant addition to other available wetland maps for the Valley. They also provide a much different picture of the distribution and abundance of potential waterbird habitat in the Valley. In general, radar remote sensing has the potential to identify both intermittent and permanent flooding not necessarily extractable from National Wetlands Inventory maps with NWI categories. There are a few practical aspects that should be considered in using these maps, however. The first is that farming practices (affecting patterns of vegetative cover) and rainfall patterns vary annually. Thus within the subset of lands with hydric soils in the Valley, the extent and distribution of shorebird habitat will vary from year to year. Moreover, although waterfowl use agricultural wetlands (Taft and Haig, unpublished data) and impounded wetlands, the maps fail to accurately map emergent ponds and shallow riparian areas also used by waterfowl and other wetland-dependent species (e.g., amphibians). This is primarily because our focus was on referencing and verifying shorebird habitat in particular. Therefore, final maps can be regarded as depicting the majority of habitat important to shorebirds but only some of the habitat important to other wetland-dependent species. Finally, radar was unable to detect linear wetlands (e.g., remnant sloughs, shallow streams) less than 3 pixels wide $(\sim 25 \mathrm{~m})$, habitat that is frequented by both waterfowl and shorebirds (Figure 2F). Consequently, these maps should be regarded as "snapshot" views of a certain kind of wetland habitat (i.e., agricultural habitat important to wintering shorebirds) in a given year of average rainfall.

\section{Summary}

The specific radar parameters we used (C-band, $\mathrm{HH}$ polarization, $38^{\circ}$ incidence angle) and our approach (single sensor, single settings for each parameter) performed well for the modest goal of mapping shorebird habitat at a relatively fine resolution on agricultural lands in winter. When cloud cover restricts the use of Landsat TM data, radar imagery may be worth acquiring for projects with objectives similar to ours, especially as the availability of imagery increases commercially and financially. Moreover, we may find increased value for radar in mapping wetland habitat for wildlife as future research refines our knowledge of radarground feature interactions and as the accuracies of maps created with radar data are further evaluated.

\section{Acknowledgements}

This work benefited greatly from the technical assistance and advice of C. Barrett, K. Bierly, G. Bonser, W. Cohen, W. Jensen, G. Lienkaemper, J. Morlan, D. Oetter, D. Peters, E. Ramsey III, P. Sanzenbacher, and T. Zarriello. R. Kennedy contributed helpful comments on early drafts of the manuscript. J. Dhundale, M. Henschen, W. Jensen, H. Packard, and P. Sanzenbacher provided invaluable assistance in collecting 
ground reference data. This study was funded by the Oregon Watershed Enhancement Board, USGS Forest and Rangeland Ecosystem Science Center, US Fish and Wildlife Service, Oregon Department of Fish and Wildlife, and US Bureau of Land Management.

\section{References}

Akins, G. J. 1970. The effects of land use and land management on the wetlands of the upper Klamath Basin. M.S. thesis. Western Washington State College, Bellingham, Washington.

Aspinall, R., and N. Veitch. 1993. Habitat mapping from satellite imagery and wildlife survey data using a Bayesian modeling procedure in a GIS. Photogrammetric Engineering and Remote Sensing 59:537-543.

Avery, T. E., and G. L. Berlin. 1992. Fundamentals of remote sensing and airphoto interpretation. 5th editionMacmillan, New York, 472 pp.

Avery, M. I., and R. H. Haines-Young. 1990. Population estimates for the Dunlin Calidris alpina derived from remotely sensed satellite imagery of the Flow Country of northern Scotland. Nature 344:860-862.

Baghdadi, N., M. Bernier, R. Gauthier, and I. Neeson. 2001. Evaluation of C-band SAR data for wetlands mapping. International Journal of Remote Sensing 22:71-88.

Benner, P. A., and J. R. Sedell. 1997. Upper Willamette River landscape: A historic perspective. Pages 23-47 in A. Laenen, and D. A. Dunnette. Eds, River quality: Dynamics and restoration. Lewis, New York.

Bernert, J. A., Eilers, J. M., Eilers, B. J., Blok, E., Daggett, S. G., Bierly, K. F. (1999) "Recent wetlands trends (1981/821994) in the Williamette Valley, Oregon, USA." Wetlands 19:545-559.

Biftu, G. F., and T. Y. Gan. 1999. Retrieving near-surface soil moisture from Radarsat SAR data. Water Resources Research 35:1569-1579.

Boulé, M. E., and K. F. Bierly. 1987. History of estuarine wetland development and alteration: What have we wrought?. Northwest Environmental Journal 3:43-61.

Bourgeau-Chavez, L. L., E. S. Kasischke, S. M. Brunzell, J. P. Mudd, K. B. Smith, and A. L. Frick. 2001. Analysis of spaceborne SAR data for wetland mapping in Virginia riparian ecosystems. International Journal of Remote Sensing 22:3665-3687.

Clark, S. E., D. White, and A. L. Schaedel. 1991. Oregon, USA, ecological regions and subregions for water quality management. Environmental Management 15:847-856.

Corbley, K. P. 1995. RADARSAT: Meeting the needs of users worldwide. Geocarto International 10:87-91.

Daggett, S. G., M. E. Boulé, J. A. Bernert, J. M. Eilers, E. Blok, D. Peters, and J. Morlan. 1998. Wetland and land use changes in the Williamette Valley, Oregon: 1982 to 1994. Report to the Oregon Division of State Lands. Shapiro and Associates, Salem, Oregon, 38 pp.

Dahl, T. E. 1990. Wetlands: Losses in the United States 1780s to 1980s. Fish and Wildlife Service, Washington, DC, 21 pp.

Dennis, N. B., and M. L. Marcus. 1984. Status and trends of
California wetlands. Environmental Science Associates, San Francisco, California, 125 pp.

Dobson, M. C., L. E. Pierce, and F. T. Ulaby. 1996. Knowledgebased land-cover classification using ERS-1/JERS-1 SAR composites. Institute of Electrical and Electronics Engineers Transactions on Geoscience and Remote Sensing 34:83-99.

Dobson, M. C., F. T. Ulaby, and L. E. Pierce. 1995. Land-cover classification and estimation of terrain attributes using synthetic aperture radar. Remote Sensing of Environment 51:199-214.

Drut, M. S., and J. B. Buchanan. 2000. The U.S. shorebird conservation plan: Northern pacific coast regional shorebird management plan. Manomet Center for Conservation Sciences, Manomet, Massachusetts, $32 \mathrm{pp}$.

Durden, S. L., L. A. Morrissey, and G. P. Livingston. 1995. Microwave backscatter and attenuation dependence on leaf area index for flooded rice fields. Institute of Electrical and Electronics Engineers Transactions on Geoscience and Remote Sensing 33:807-810.

Dwivedi, R. S., B. R. M. Rao, and S. Bhattacharya. 1999. Mapping wetlands of the Sundaban Delta and its environs using ERS-1 SAR data. International Journal of Remote Sensing 20:2235-2247.

Elachi, C. 1988. Spaceborne radar remote sensing: Applications and techniques. Institute of Electrical and Electronics Engineers Press, New York, 255 pp.

Fuller, R. M., P. Ipulet, D. Pomeroy, A. Katende, R. Bailey, R. Ogutu-Ohwayo, G. B. Groom, and S. Mugisha. 1998. The integration of field survey and remote sensing for biodiversity assessment: A case study in the tropical forests and wetlands of Sango Bay, Uganda. Biological Conservation 86:379-391.

Gilligan J., D. Rogers, M. Smith, and A. Contreras. Eds, 1994. Birds of Oregon: Status and distribution. Cinclus, McMinnville, Oregon, 330 pp.

Good, J. W., and C. B. Sawyer. 1998. Recommendations for a nonregulatory wetland restoration program for Oregon. Oregon Sea Grant, Corvallis, Oregon, 96 pp.

Goss-Custard, J. D., and M. G. Yates. 1992. Towards predicting the effect of salt-marsh reclamation on feeding bird numbers on the Wash. Journal of Applied Ecology 29:330-340.

Gratto-Trevor, C. L. 1996. Use of Landsat TM imagery in determining important shorebird habitat in the Outer Mackenzie Delta, Northwest Territories. Arctic 49:11-22.

Henderson, F. M., R. Chasan, T. F. Hart Jr., and J. Portolese. 1998. Variation in SAR signal response from coastal wetlands in a complex urban setting. Pages 487-492 in Proceedings of the 2nd international workshop on retrieval of bio- and geo-physical parameters from SAR data for land applications, 21-23 October. ESTEC, Noordwijk, The Netherlands.

Henderson, F. M., T. F. Hart Jr, B. P. Heaton, and J. E. Portolese. 1999. Mapping coastal ecosystems over a steep development gradient using C-CAP protocols. International Journal of Remote Sensing 20:727-744.

Hess, L. L., and J. M. Melack. 1994. Mapping wetland hydrology and vegetation with synthetic aperture radar. International Journal of Ecology and Environmental Sciences 20:197-205. 
Hulse, D., Branscomb, A., Giocochea-Duclos, J., Gregory, S., Ashkenas, L., Minear, P., Payne, S., Richey, D., Dearborn, H., Christy, J., Alverson, E., Richmond, M. 1998. Willamette River Basin planning atlas, 1st ed. Pacific Northwest Ecosystem Research Consortium, Institute for a Sustainable Environment, University of Oregon, Eugene, Oregon, 72 pp.

Jackson, P. L., and A. J. Kimerling. 1993. Atlas of the Pacific Northwest. Oregon State University Press, Corvallis, Oregon, $152 \mathrm{pp}$.

Jacobson, J. E. 1991. An operational program for the inventory of waterfowl habitat. American Congress on Surveying and Mapping/American Society for Photogrammetry and Remote Sensing 3:215-223.

Jensen, J. R., H. E. Mackey Jr, E. J. Christensen, and R. R. Sharitz. 1987. Inland wetland change detection using aircraft MSS data. Photogrammetric Engineering and Remote Sensing 35:521-529.

Jensen, J. R., D. J. Cowen, J. D. Althausen, and S. Narumalani. 1993. An evaluation of the CoastWatch change detection protocol in South Carolina. Photogrammetric Engineering and Remote Sensing 59:1039-1046.

Johnson, J. 1993. Fieldnotes: Western Oregon, winter 199293. Oregon Birds 19:86-88.

Kasischke, E. S., and L. L. Bourgeau-Chavez. 1997. Monitoring south Florida wetlands using ERS-1 SAR Imagery. Photogrammetric Engineering and Remote Sensing 63:281-291.

Kasischke, E. S., J. M. Melack, and M. C. Dobson. 1997. The use of imaging radars for ecological applications-A review. Remote Sensing of Environment 59:141-156.

Kempka, R. G., R. P. Kollasch, and G. T. Koeln. 1992. Ducks Unlimited: Using GIS to preserve the Pacific Flyway's wetland resource. GIS World 5:46-52.

Kiilsgaard, C. 1999. Oregon vegetation: Mapping and classification of landscape-level cover types. Final report. USGSBRD GAP Analysis Program, Moscow, Idaho, 22 pp.

Lee, K. H., and R. S. Lunetta. 1995. Wetland detection methods. Pages 249-284 in J. G. Lyon, and J. McCarthy. Eds, Wetland and environmental applications in GIS. Lewis, Boca Raton, Florida.

Lunetta, R. S., and M. E. Balogh. 1999. Application of multitemporal Landsat 5 TM imagery for wetland identification. Photogrammetric Engineering and Remote Sensing 65:1303-1310.

Metternicht, G. I. 1999. Current status and future prospects of radar remote sensing for cartographic applications. Cartography 28:1-17.

Mitsch, W. J., and J. G. Gosselink. 2000. Wetlands, 3rd ed. John Wiley and Sons, New York, 920 pp.

Morlan, J. C. 2000. Summary of current status and health of Oregon's freshwater wetlands. Pages 45-52 in Oregon state of environment report 2000. Division of State Lands, Salem, Oregon.

Morrison, R. I. G. 1997. The use of remote sensing to evaluate shorebird habitats and populations on Prince Charles Island, Foxe Basin, Canada. Arctic 50:55-75.

Nehls, H. B. 1994. Oregon shorebirds: Their status and movements. Technical Report 94-1-02. Oregon Department of Fish and Wildlife, Portland, Oregon, 58 pp.

Oetter, D. R., W. B. Cohen, M. Berterretche, T. K. Maier- sperger, and R. E. Kennedy. 2000. Land cover mapping in an agricultural setting using multiseasonal Thematic Mapper data. Remote Sensing of Environment 76:139-155.

Ormsby, J. P., B. J. Blanchard, and A. J. Blanchard. 1985. Detection of lowland flooding using active microwave systems. Photogrammetric Engineering and Remote Sensing 51:317-328.

Pater, D. E., S. Bryce, T. D. Thorson, J. Kagan, C. Chappell, J. Omernik, S. Azevedo, and A. J. Woods. 1997. Ecoregions of western Washington and Oregon. US Environmental Protection Agency, Corvallis, Oregon.

Pietroniro, A., Leconte, R., Peters, D. L., Prowse, T. D. 2000. Application of a hydrodynamic model in a freshwater delta using remote sensing. Pages 519-525 in IAHS-AISH Publication No. 267, Remote sensing and hydrology 2000_Proceedings of a symposium, April. Santa Fe, New Mexico.

Place, J. L. 1985. Mapping of forested wetland: Use of Seasat RADAR images to complement conventional sources. Professional Geographer 37:463-469.

Ramsey III, E. W. 1995. Monitoring flooding in coastal wetlands by using radar imagery and ground-based measurements. International Journal of Remote Sensing 16:2495-2502.

Ramsey III, E. W. 1999. Radar remote sensing of wetlands. Pages 211-243 in R. S. Lunetta, and C. D. Elvidge. Eds, Remote sensing change detection. Ann Arbor Press, Chelsea, Michigan.

Ramsey III, E. W., G. A. Nelson, and S. K. Sapkota. 1998. Classifying coastal resources by integrating optical and radar imagery and color infrared photography. Mangroves and Salt Marshes 2:109-119.

Rio, J. N. R., and D. F. Lozano-Garcia. 2000. Spatial filtering of radar data (RADARSAT) for wetlands (brackish marshes) classification. Remote Sensing of Environment 73:143-151.

Sanzenbacher, P. M., and S. M. Haig. 2002a. Residency and movement patterns of wintering Dunlin in the Willamette Valley of Oregon. Condor 104:271-280.

Sanzenbacher, P. M., and S. M. Haig. 2002b. Regional fidelity and movement patterns of wintering Killdeer in an agricultural landscape. Waterbirds 25:16-25.

Scott, J. M., P. J. Heglund, and M. L. Morrison. 2002. Predicting species occurrences: Issues of accuracy and scale. Island Press, Washington, DC, 840 pp.

Sokol, J., Pultz, T. J., Bulzgis, V. 2000. Monitoring wetland hydrology in Atlantic Canada using multi-temporal and multi-beam Radarsat data. Pages 536-538 in IAHS-AISH Publication No. 267, Remote sensing and hydrology 2000-Proceedings of a symposium, April. Santa Fe, New Mexico.

Taft, O. W., and S. M. Haig. 2003. Historical wetlands in Oregon's Willamette Valley: Implications for restoration of winter waterbird habitat. Wetlands 23:51-64.

Töyrä, J., A. Pietroniro, and L. W. Martz. 2001. Multisensor hydrologic assessment of a freshwater wetland. Remote Sensing of Environment 75:162-173.

Turner, M. G. 1989. Landscape ecology: The effect of pattern on process. Annual Review of Ecology and Systematics 20:171-197.

US Fish and Wildlife Service 1991. Status of National Wetlands Inventory: Region 1. USFWS, Portland, Oregon. 
Wang, Y., L. L. Hess, S. Filoso, and J. M. Melack. 1995. Understanding the radar backscattering from flooded and nonflooded Amazonian forests: Results from canopy backscatter modeling. Remote Sensing of Environment 54:324-332.

Wickware, G. M., Sims, R. A., Ross, R. K., Cowell, D. W. 1980.
The application of remote sensing techniques for an ecological land survey of the Snow Goose colony at Cape Henrietta Maria, Hudson Bay. Pages 387-395 in Proceedings of the Sixth Canadian Symposium on Remote Sensing. Halifax, Nova Scotia. 